\title{
Application of the Markov Chain in Macroeconomic Analysis of a Managed Forest in the Amazon
}

\author{
M. H. A. Acuña ${ }^{1}$, L. C. Oliveira ${ }^{2}$, M. V. N. D’Oliveira ${ }^{2}$, M. B. Souza ${ }^{1} \&$ C. A. F. da Costa $^{1}$ \\ ${ }^{1}$ REDE-BIONORTE, Universidade Federal do Acre, Brazil \\ ${ }^{2}$ PPG-BIONORTE, Empresa Brasileira de Pesquisa Agropecuária, Brazil \\ Correspondence: M. V. N. D’Oliveira, PPG-BIONORTE, Empresa Brasileira de Pesquisa Agropecuária, \\ Campus Universitário, Rodovia BR 364, Km 04, Distrito Industrial, Caixa Postal 500, Rio Branco, AC, Brazil. \\ E-mail: mhaacuna@gmail.com
}

Received: April 1, $2019 \quad$ Accepted: May 25, $2019 \quad$ Online Published: July 31, 2019

doi:10.5539/jas.v11n11p172 URL: https://doi.org/10.5539/jas.v11n11p172

\begin{abstract}
This study includes an economic analysis of the dynamics and prognosis of the forest structure of an area under sustainable forest management in the Amazon, in the primary production of tropical roundwood. It analyzes measurements taken between 2001 and 2011 and carries out forest forecasting for the period from 2001 to 2021 with the application of the Markov Matrix Chain. The variables measured by the probability matrix were transformed into equivalent annual rates and compared over the same period to the Brazilian macroeconomic indicators of gross domestic product (GDP) and the real interest rate of primary roundwood production (TJLP). The valuation of tree density utilized a series of average prices of world imports and exports of roundwood. Between 2001 and 2011, the parameters of the forest dynamics without valuation were similar to the TJLP (1.4\% per year) and, when valued, the rates were close to the GDP of 3.5\% per year. The forecast from 2001 to 2021 indicates that unrated economic groups behave in a similar way to the TJLP of $1 \%$ per annum and to the GDP of $2.2 \%$ per year, except the recovery category, which has a negative rate of $1.9 \%$ per year. The monitoring of tropical forests allows the achievement of economic indexes capable of assessing the anthropic and natural impacts in short periods of analysis and projecting them over time on natural capital.
\end{abstract}

Keywords: Amazon, forest dynamics, forest forecasting, economics and natural resources

\section{Introduction}

Social capital represents the sum of the benefits that ecosystems offer to human kind (Georgescu-Roegen, 1971; Naredo, 1987; Daly, 1999). The United Nations Convention on Biological Diversity recognizes the intrinsic, ecological, economic, scientific, educational, cultural, recreational and aesthetic value of biological diversity and its components (CBD, 2010).

Sustainable forest management is the tool applied in managing the extraction of roundwood in the tropical forests of the Amazon, Asia and Africa. Its objective is to reduce the effects of logging intensity and to highlight the variables that affect forest dynamics and tree density structure. The study of forest dynamics considers the growth, recruitment and mortality of tree density (Sheil et al., 2000; Blanc et al., 2009; West et al., 2014, D’Oliveira et al., 2017).

The application of sustainable forest management is related to global concern with tropical forests, as they play a vital role for life on the planet by storing carbon and greenhouse gases in complex sinks and in global climate regulation (Pan et al., 2011).

In recent years, tropical forests have declined in size and today represent a finite and vulnerable resource (Food and Agriculture Organization of the United Nations [FAO], 2015). In the Amazon, in addition to illegal deforestation, atypical climatic events have impacted forests in the last decades, harming their net primary productivity due to increased tree mortality and causing ecological, social and economic damages (Baker et al., 2004; Nepstad et al., 2004; Boisvenue \& Running, 2006; Higuchi \& Clement, 2006; Negrón-Juarez et al., 2010; Toledo et al., 2011; D’Oliveira et al., 2017).

To monitor human and natural effects and to estimate productivity, it is necessary to carry out forest monitoring, which is the basis of sustainable forest management (D'Oliveira et al., 2017). By convention, the sustainability 
tripod in natural resource management must be: socially just, ecologically correct, and economically efficient, which requires monitoring to correct management failures, future choices of use and sustainability. However, the economy does not calculate the evolution of nature's stocks, causing a gap in understanding the ecological crisis of the planet's natural resources (Georgescu-Roegen, 1971).

As a result of the gap shown by Georgescu-Roegen, society and governments do not value biodiversity and its elements, disregarding it in national accounts as well as omitting it from gross domestic product (GDP) and the human development index (HDI). This generated AICHI's Goal-II for Convention of Biological Diversity [CDB] in 2020 (CDB, 2010; Weigrand et al., 2011). In turn, ecological economics and its foundations consider natural stocks and the evolution of their production and regeneration capacity from a transdisciplinary and eco-integrative perspective, accepting the traditional economic tools and using them, but recognizing their incapacity in the analysis of productivity ecosystems. It is a transdisciplinary approach because it applies various sciences in the study, and it is eco-integrative because it values natural resources alongside economic parameters (Georgescu-Roegen, 1971).

For the Organisation for Economic Cooperation and Development [OECD] (2009), ecological economics represents the contribution of biotechnology to economic production, since it is related in real time to sustainable development and environmental sustainability and is composed of three elements: i) biotechnology; ii) knowledge of renewable biomass; and iii) integration among the applications used. Consequently, the concept of sustainability must strive for the economic rationality of the management of natural resources to reduce costs and maximize structural gains, and with that to meet the current and future demands of society (Georgescu-Roegen, 1971; Naredo, 1987; Carpintero-Redondo, 1999; Daly, 2004; Costa \& Montysuma, 2016).

Thus, the objective of this study was to develop a model of analysis capable of evaluating post-logging forest dynamics between 2001 and 2011 in an area under sustainable forest management in the Amazon and to carry out forestry forecasting for the period from 2001 to 2021, transforming its indicator into equivalent annual rates to be compared, over the same periods, to the following macroeconomic indicators in Brazil: i) Gross Domestic Product (GDP); ii) the Brazilian Development Bank's (BNDES) financing rate of primary production; iii) inflation; iv) the economy's exchange rate correction; and the series of international tropical timber prices.

\section{Method}

\subsection{Study Area}

The study area is located in the state of Acre, in the Southwestern Brazilian Amazon $\left(68^{\circ} 01^{\prime}\right.$ to $68^{\circ} 23^{\prime} \mathrm{W}$; $9^{\circ} 13^{\prime}$ to $9^{\circ} 31^{\prime} \mathrm{S}$ ) in Antymari State Forest, Bujari, Acre (Figure 1). The area’s forest typology is an open ombrophilous forest with the occurrence of Guadua spp. (local bamboo species), with an Awi (Köppen) type climate, annual precipitation of $2000 \mathrm{~mm}$ with a dry season from June to September, an average temperature of $25^{\circ} \mathrm{C}$ and relief between 100 and $300 \mathrm{~m}$ (FUNTAC, 1989). In 2005 and 2010, atypical climatic events were recorded in the Amazon and strong storms in the Amazonian winter of 2010-2011.
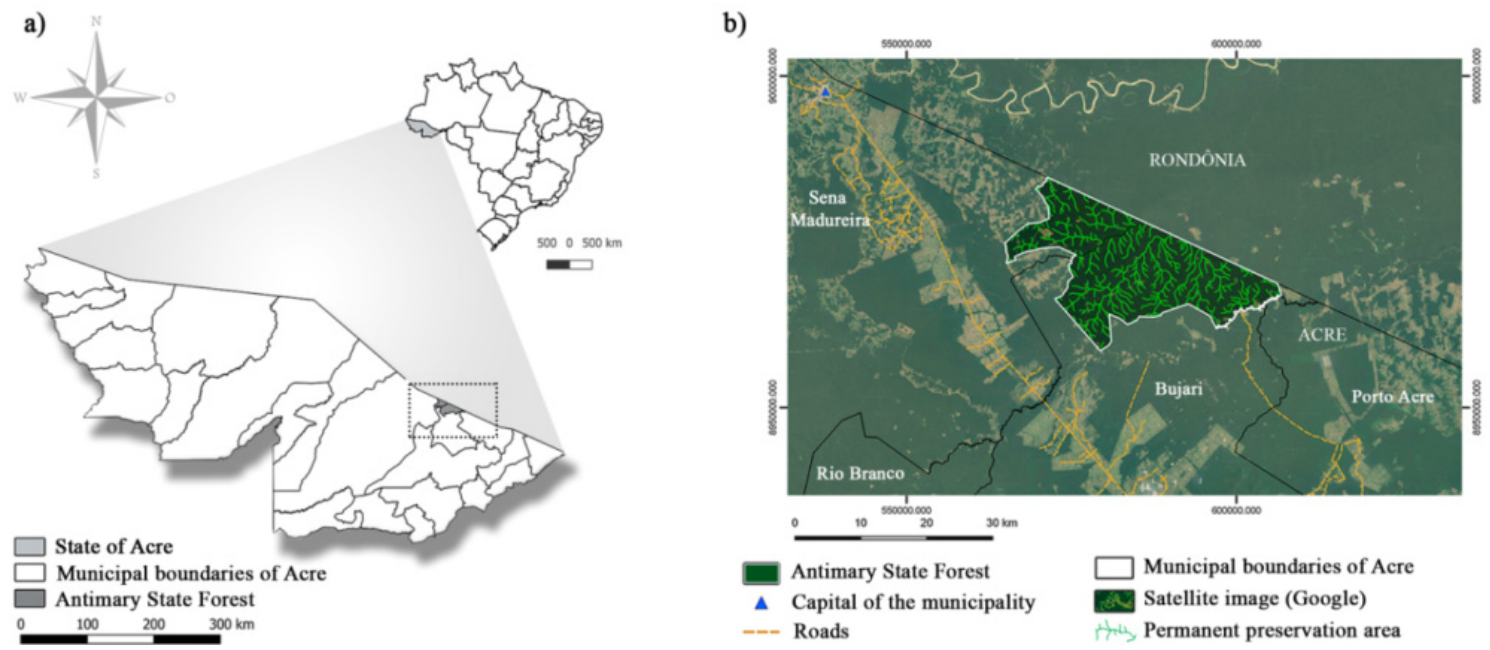

Figure 1. Antimary state forest, acre state, southwestern brazilian amazon 


\subsection{Forest Dynamics Parameters}

In the period between 2001 and 2011, the forest dynamics information (growth, recruitment and mortality of trees) comes from the forest monitoring of 10 permanent sample plots of 1 hectare (ha). These were set up by the Brazilian Agricultural Research Company (EMBRAPA) in 1999 for the measurements of diameter at breast height, or 1.3 meters (m) from the soil (DBH) in the years 1999, 2001, 2004, 2007, 2011 and 2016. The selective extraction of tropical roundwood occurred in 2000 with logging intensity of $6.9 \mathrm{~m}^{3} \mathrm{ha}^{-1}$. Although it was not part of the study, a high mortality rate of Guadua spp. was observed in 2004. No silvicultural treatments were performed during the period.

In the analysis, all trees with DBH greater than or equal to $20 \mathrm{~cm}$ were measured and divided into: a) diametric classes of $10 \mathrm{~cm}$ of amplitude, named by the midpoint $(25 ; 35 ; \ldots 125 \mathrm{~cm})$; and b) size classes: i) $\mathrm{DBH} \geq 20<30$ cm; ii) $\mathrm{DBH} \geq 30<50 \mathrm{~cm}$; iii) $\mathrm{DBH} \geq 50<80 \mathrm{~cm}$; iv) $\mathrm{DBH} \geq 80 \mathrm{~cm}$.

The estimates considered tree density (the mean number of trees per hectare) and above ground dry biomass. The above ground dry biomass (AGB) was estimated using the equation developed by Nogueira et al. (2008):

$$
A G B=\operatorname{EXP}[-1.716+2.413 \times L N(D B H \mathrm{~mm} / 10)] / 1000
$$

Where, $A G B$ : biomass; EXP: exponential function; $L N$ : natural logarithm; $D B H$ : diameter at breast height

The percentage indexes were transformed to effective annual rates by the equation:

$$
T x \% a a=[(A G B+1) /(A G B+0)]^{1 / n}
$$

Where, $T x \% a a$ : annual rate; $A G B+1$ : value of future observed AGB in the class; $A G B+0$ : value of observed AGB in the previous measurement in the class; $n$ : is the time interval between measurements in years.

The annual recruitment rate, or number of new trees that reached a $\mathrm{DBH} \geq 20 \mathrm{~cm}$, was estimated using the equation (Schneider, 2004):

$$
\text { TaaR }=\left\{\left[1+\left(\sum R_{1} / \sum V_{0}\right)^{1 / t}\right]-1\right\} \times 100
$$

Where, TaaR: annual recruitment rate; $\sum R_{1}$ : total number of trees recruited expressed in the studied period; $\sum V_{0}$ : total number of living individuals in the current measurement and $t$ : the time interval between measurements in years.

The mortality rate was estimated according to the formula by Sheil et al. (2000):

$$
\text { TaaM }=\left\{\left[1+\left(\sum M_{1} / \sum M_{0}\right)^{1 / t}\right]-1\right\} \times 100
$$

Where, TaaM: annual mortality rate; $M_{1}$ : number of dead trees between analyzed measurements; $M 0$ : number of live trees in the previous measurement.

The growth or evolution of stocks was calculated using the equation (D'Oliveira et al., 2013; 2017):

$$
\text { TaaC }=\left\{\left[1+\left(\sum N_{t+1} / \sum N_{t}\right)^{1 / t}\right]-1\right\} \times 100
$$

Where, Taac: annual growth rate (\%); $\sum N_{t+1}$ : sum of the number of live trees at measurement $t+1 ; \sum N t$ : sum of live trees at measurement $t$.

\subsection{Probabilistic Transition Matrix-Markov Chain}

In order to predict the forest structure for 2021, based on the 2001-2011 observations, we used the mathematical and probabilistic method of the Markov Chain (Kolmogorov \&Aleksandrov, 1956), applied in studies of forest dynamics in the Amazon (Higuchi, 1987; Teixeira et al., 2007; Vasconcelos et al., 2009; Acuña, 2015).

To structure the Markov chain the population was divided into size classes (diametric classes with amplitude of $10 \mathrm{~cm}$ ) to establish the matrix of probabilistic transition among the size classes. The possible transitions were: i) stay in size class; ii) change the size class (forward); iii) ingress of new individuals (recruitment) into the population and iv) mortality (Table 1). We used 13 size classes to define the matrix, where a11; a12; a13; correspond to recruitment (R); a21 to a1211 correspond to size classes, with a21 $(20 \leq \mathrm{DBH}<30 \mathrm{~cm})$ the first size class and a1211 $(\mathrm{DBH} \geq 120 \mathrm{~cm})$ the last class; a212 to a812 correspond to mortality $(\mathrm{M})$. 
Table 1. Diameter classes transition matrix (number of trees DBH $\geq 20 \mathrm{~cm}$ ) to the period from 2001 to 2011 . Cd-diameter classes; R-recruitment of trees with $\mathrm{DBH} \geq 20 \mathrm{~cm}$; M-mortality

\begin{tabular}{|c|c|c|c|c|c|c|c|c|c|c|c|c|c|}
\hline Cd & 25 & 35 & 45 & 55 & 65 & 75 & 85 & 95 & 105 & 115 & 125 & $\mathbf{M}$ & 2001 \\
\hline $\mathbf{R}$ & 493 & 62 & 9 & 5 & & & & & & & & & 569 \\
\hline 25 & 398 & 151 & 9 & 2 & & & & & & & & 162 & 722 \\
\hline 35 & & 176 & 95 & 2 & 1 & 3 & & & & & & 57 & 334 \\
\hline 45 & & & 77 & 30 & 6 & & & & & & & 41 & 154 \\
\hline 55 & & & & 30 & 16 & 4 & & & & & & 19 & 69 \\
\hline 65 & & & & & 15 & 6 & 1 & & & & & 10 & 32 \\
\hline 75 & & & & & & 6 & 1 & 1 & & & & 3 & 11 \\
\hline 85 & & & & & & & 3 & 6 & & & & 2 & 11 \\
\hline 95 & & & & & & & & 2 & 1 & 1 & & & 4 \\
\hline 105 & & & & & & & & & 2 & 2 & & & 4 \\
\hline 115 & & & & & & & & & & & 2 & & 2 \\
\hline 125 & & & & & & & & & & & 1 & & 1 \\
\hline 2011 & 891 & 389 & 190 & 69 & 38 & 19 & 5 & 9 & 3 & 3 & 3 & 294 & 1913 \\
\hline
\end{tabular}

From the transition matrix of the 2001 to 2011 interval, we made the matrix of probabilistic transition $\left(P_{i j}\right)$, which represents the probabilities of transition among the size classes calculated trough the densities in each size class (Higuchi, 1987), using the equation below:

$$
P_{i j}=n_{i j} / N_{i j}
$$

Where, $P_{i j}$ : probability of occurrence of trees in the size class $i j$ in time $t 1 ; n_{i j}$ : trees in the size class $i j$ in time $t$ and $N_{i j}$ : trees in the size class $i j$ in time $t 1$.

Table 2. Diameter classes probabilistic transition matrix (trees DBH $\geq 20 \mathrm{~cm}$ ) to the period from 2001 to 2011 . Cd-diametric class (cm); R-recruitment; M-mortality

\begin{tabular}{|c|c|c|c|c|c|c|c|c|c|c|c|c|}
\hline Cd & 25 & 35 & 45 & 55 & 65 & 75 & 85 & 95 & 105 & 115 & 125 & M \\
\hline $\mathbf{R}$ & 0.866 & 0.109 & 0.016 & 0.009 & & & & & & & & \\
\hline 25 & 0.551 & 0.209 & 0.012 & 0.003 & & & & & & & & 0.224 \\
\hline 35 & & 0.527 & 0.284 & 0.006 & 0.003 & 0.009 & & & & & & 0.171 \\
\hline 45 & & & 0.500 & 0.195 & 0.039 & & & & & & & 0.266 \\
\hline 55 & & & & 0.435 & 0.232 & 0.058 & & & & & & 0.275 \\
\hline 65 & & & & & 0.469 & 0.188 & 0.031 & & & & & 0.313 \\
\hline 75 & & & & & & 0.545 & 0.091 & 0.091 & & & & 0.273 \\
\hline 85 & & & & & & & 0.273 & 0.545 & & & & 0.182 \\
\hline 95 & & & & & & & & 0.500 & 0.250 & 0.250 & & \\
\hline 105 & & & & & & & & & 0.500 & 0.500 & & \\
\hline 115 & & & & & & & & & & & 1.000 & \\
\hline 125 & & & & & & & & & & & 1.000 & \\
\hline
\end{tabular}

Based on the result of the probability transition matrix, the transition matrix for the year 2011 was built, or time $t$ +2 (two steps ahead), to determine the forecast of diameter distribution between 2001 and 2021, using the equation:

$$
P(n)=P n
$$

Where, $P(n)$ : Matrix of probabilistic transition to $n^{\text {th }}$ period; $P n$ : Matrix of probabilistic transition elevated to the $n^{\text {th }}$ power (Table 3 ). 
Table 3. 'Two steps ahead' period probabilistic transition matrix, forecast for 2021

\begin{tabular}{|c|c|c|c|c|c|c|c|c|c|c|c|c|}
\hline Cd & 25 & 35 & 45 & 55 & 65 & 75 & 85 & 95 & 105 & 115 & 125 & $\mathbf{M}$ \\
\hline $\mathbf{R}$ & 0.478 & 0.239 & 0.050 & 0.010 & 0.003 & 0.001 & & & & & & \\
\hline 25 & 0.304 & 0.225 & 0.073 & 0.006 & 0.002 & 0.002 & & & & & & 0.163 \\
\hline 35 & & 0.278 & 0.292 & 0.061 & 0.015 & 0.011 & 0.001 & 0.001 & & & & 0.171 \\
\hline 45 & & & 0.250 & 0.182 & 0.083 & 0.019 & 0.001 & & & & & 0.199 \\
\hline 55 & & & & 0.189 & 0.210 & 0.100 & 0.013 & 0.005 & & & & 0.208 \\
\hline 65 & & & & & 0.220 & 0.190 & 0.040 & 0.034 & & & & 0.203 \\
\hline 75 & & & & & & 0.298 & 0.074 & 0.145 & 0.023 & 0.023 & & 0.165 \\
\hline 85 & & & & & & & 0.074 & 0.421 & 0.136 & 0.136 & & 0.050 \\
\hline 95 & & & & & & & & 0.250 & 0.250 & 0.250 & 0.250 & \\
\hline 105 & & & & & & & & & 0.250 & 0.250 & 0.500 & \\
\hline 115 & & & & & & & & & & & 1.000 & \\
\hline 125 & & & & & & & & & & & 1.000 & \\
\hline
\end{tabular}

Based on the matrix of the period 2001 to 2011 squared (two steps ahead) the number of trees for each size class was projected to 2021. Mortality and recruitment were also predicted (Table 4). The projected distribution by size class for 2021 was compared with that observed in 2016 through the chi-square test at $1 \%$ of significance (p $<0.01)$.

Table 4. Tree density (number of trees DBH $\geq 20 \mathrm{~cm}$ ) according to diameter classes, observed (o) in the permanent sample plots in 2001, 2011 and 2016 and predicted (p) for 2021

\begin{tabular}{lllll}
\hline Cd & $\mathbf{0 - 2 0 0 1}$ & $\mathbf{0 - 2 0 1 1}$ & $\mathbf{0 - 2 0 1 6}$ & $\mathbf{p - 2 0 2 1}$ \\
\hline 25 & 722 & 891 & 756 & 491 \\
35 & 334 & 389 & 380 & 391 \\
45 & 154 & 190 & 180 & 217 \\
55 & 69 & 69 & 66 & 72 \\
65 & 32 & 38 & 43 & 42 \\
75 & 11 & 19 & 12 & 25 \\
85 & 11 & 5 & 6 & 4 \\
95 & 4 & 9 & 9 & 9 \\
105 & 4 & 3 & 3 & 4 \\
115 & 2 & 3 & 2 & 4 \\
125 & 1 & 3 & 3 & 7 \\
- Total & $\mathbf{1 3 4 4}$ & $\mathbf{1 6 1 9}$ & $\mathbf{1 2 6 6}$ \\
\hline
\end{tabular}

Note. $(*)$ : Chi Square of the frequency distribution observed in 2016 and forecast to 2021 with all classes, $(\mathrm{GL}=$ 10 , value $=54.04, \mathrm{p}<.0001) ;(* *)$ : Chi Square of the frequency distribution observed in 2016 and projected to 2021 without the $25 \mathrm{~cm}$ class, $(\mathrm{GL}=9$ value $=7.86, \mathrm{p}=0.55)$.

\subsection{Economic Parameters}

The results of forest dynamics obtained by the Markov Chain in the period from 2001 to 2011 and the forecast from 2001 to 2021 were transformed into annualized equivalent rate parameters and compared in the same time interval with official Brazilian macro-economic indices expressed in annual rates: i) Gross Domestic Product (GDP); ii) BNDES Long-Term Interest Rate; iii) Inflation correction; iv) Foreign exchange correction; and with the international price series of tropical roundwood (information obtained from ITTO, 2012-2017).

To transform the AGB values expressed in size classes to economic parameters we adopted the following definitions: i) Capital recovery-corresponds to recruitment of trees with $\mathrm{DBH} \geq 20 \mathrm{~cm}$; ii) Capital formation-AGB of the trees that stayed in their size class $(30 \leq \mathrm{DBH}<40 \mathrm{~cm}$ and $40 \leq \mathrm{DBH}<50 \mathrm{~cm})$ added to those that changed their size class $(20 \leq \mathrm{DBH}<30 \mathrm{~cm}$ and $40 \leq \mathrm{DBH}<50 \mathrm{~cm})$; iii) Available capital-AGB available for forest logging $(50 \leq \mathrm{DBH}<80 \mathrm{~cm})$; iv) Capital funding-AGB immobilized in trees $\mathrm{DBH} \geq 80 \mathrm{~cm}$; iv. Capital loss - Represented by AGB lost by mortality in all size classes. 
To calculate the valuation of the natural capital, expressed in AGB, we used $11 \%$ correction factors which correspond to the percent of marketable species in the forest tree population (DBH $\geq 20 \mathrm{~cm}$ ) following the results of d'Oliveira et al. (2013). The annual valuation rate of the tropical roundwood was calculated based on the time series of the world exportation retail price in the 2001-2014 period and the forecasts to 2021 (ITTO, 2017).

To estimate the GDP to 2021 we used the Brazilian indexes observed in the 2001 to 2017 period and the forecast to 2021 (Central Bank of Brazil [BACEN], 2017, 2018).

The real long-term financing interest rate applied (TJRLP) from 2001 to 2017 and the projection for 2021 were calculated from the exponential difference between the BNDES financing interest rate for primary production and the inflation correction according to the National Consumer Price Index in Brazil (BNDES, 2018; BACEN, 2018) from 2001 to 2011 and in the interval from 2001 to 2021, considering the official forecasts for 2017 to 2021. The results were indexed by the exchange rate correction of the Brazilian currency against the US dollar in the same period of time.

\section{Results}

\subsection{Forest Dynamic Parameters-Markov Chain}

The change of states determined by the $t+1$ transition matrix, expressed as tree density per diametric class, mortality and recruitment in 101 ha permanent sample plots monitored from 2001 to 2011, is shown in Table 1. Trees that grew enough to change one or more DBH classes are on the right of the main diagonal (in bold). The recruitment of new trees totaled 569 distributed among the classes with a midpoint between $25 \mathrm{~cm}$ and $55 \mathrm{~cm}$. Mortality represented 294 trees.

The consolidated total of 1913 trees corresponds to the number of live trees in all diametric classes observed in 2001, added to the recruitment between 2001 and 2011 (last column), the sum of the trees observed in 2011 and the mortality in the period (last row). The probabilistic transition matrix from one state (i) to another (j) in the period from 2001 to 2011 is presented in Table 2.

Recruitment divided by size classes showed that $87 \%$ was in class $20 \leq \mathrm{DBH}<30 \mathrm{~cm}, 10.9 \%$ in class $30 \leq \mathrm{DBH}$ $<40 \mathrm{~cm}$ and $2.5 \%$ in classes up to $40 \leq \mathrm{DBH}<60 \mathrm{~cm}$.

The average time that trees spent in their original state was $50 \%$ in the classes with the highest tree density $(20 \leq$ DBH $<80 \mathrm{~cm}$ ). In the larger classes, the time spent was lower, due to the smaller number of trees. The change of state of a class presented rates between $18.8 \%(60 \leq \mathrm{DBH}<70 \mathrm{~cm})$ and $28.4 \%(30 \leq \mathrm{DBH}<40 \mathrm{~cm})$ in the classes between $20 \leq \mathrm{DBH}<80 \mathrm{~cm}$. In the period, mortality rates ranged from $17.1 \%(30 \leq \mathrm{DBH}<40 \mathrm{~cm})$ to $31.3 \%(60 \leq \mathrm{DBH}<70 \mathrm{~cm})$, without showing a specific trend.

The two steps ahead for the $2021(t+2)$ probabilistic transition matrix, based on the tree density observed between 2001 and $2011(t+1)$, is presented in Table 3. The recruitment foreseen for 2021 is distributed between the classes of 20 to $80 \mathrm{~cm}$, of which $47.8 \%$ is in the $20 \leq \mathrm{DAP}<30 \mathrm{~cm}$ class, $2.39 \%$ in the $30 \leq \mathrm{DAP}<40 \mathrm{~cm}$ class, $5 \%$ in the $40 \leq \mathrm{DAP}<50 \mathrm{~cm}$ class, $1 \%$ in the $50 \leq \mathrm{DAP}<60 \mathrm{~cm}$ class and $0.1 \%$ in the $70 \leq \mathrm{DAP}<80 \mathrm{~cm}$ class. Recruitment rates predicted for 2021 were lower than those observed between 2001 and 2011 (Table 3).

The change of one diameter class presented rates between $18.8 \%(70 \leq \mathrm{DAP}<80 \mathrm{~cm})$ and $28.4 \%(30 \leq \mathrm{DAP}<$ $40 \mathrm{~cm})$. Mortality rates ranged from $17.1 \%(30 \leq \mathrm{DAP}<40 \mathrm{~cm})$ to $31.3 \%(60 \leq \mathrm{DAP}<70 \mathrm{~cm})$ without a specific trend. When we projected the two steps ahead matrix (20yr.), the probability of changes in state increased, for example, in the observed period 2001-2011 this change occurred in four classes (Table 2), and in the forecast from 2001 to 2021 it occurred in six classes (Table 3).

The forecast for mortality for the 2001-2021 period (based on the forest dynamics parameters calculated for the 2001 and 2011 period) predicted a mortality rate of $5 \%$ for the $80 \leq \mathrm{DBH}<90 \mathrm{~cm}$ class. In the lower classes this rate varied from $16.3 \%(20 \leq \mathrm{DBH}<30 \mathrm{~cm})$ to $20.8 \%(50 \leq \mathrm{DBH}<60 \mathrm{~cm})$. There was no mortality prediction for classes larger than $85 \mathrm{~cm}$, since in the period from 2001 to 2011 no mortality occurred.

The number of trees by size class predicted for 2021 by the Markov Chain is shown in Table 4 . We used the 2016 measurement to evaluate the adjustment of the projected distribution for 2021 (Chi-square test with $\mathrm{p}<0.01$ ). The observed distribution (2016) and the projected distribution for 2021 were tested. The result showed that when class $20 \leq \mathrm{DAP}<30 \mathrm{~cm}$ was withdrawn from the analyses the distributions did not differ significantly (GL $=9 ; \mathrm{p}=0.55$ ).

The Markov Chain forecast for 2021 indicates a decrease in total tree density from 1344 in 2001 to 1266 in 2021, which is the same tendency observed in the permanent sample plots between 2001 and 2016. The decrease in 
tree density was predicted for the $20 \leq \mathrm{DBH}<30 \mathrm{~cm}$ class, which composes the capital replenishment category with $\mathrm{DBH} \geq 20 \mathrm{~cm}$. In classes with $\mathrm{DBH} \geq 80 \mathrm{~cm}$, there was a forecast for tree density increase from 22 trees in 2001 to 28 in 2021 . In the class of $70 \leq \mathrm{DBH}<80 \mathrm{~cm}$ the forecast indicates an increase from 11 trees in 2001 to 25 in 2021 .

The mortality rates estimated for the measurement periods of 2001 to $2004 ; 2004$ to 2007; 2007 to $2011 ; 2001$ to 2011 and those forecast for the period from 2001 to 2021 are shown in Figure 2. In Figure 2 (a) and (b), the highest mortality rates were found in the time intervals from 2007-2011 and 2001-2011, seven and eleven years after forest logging.
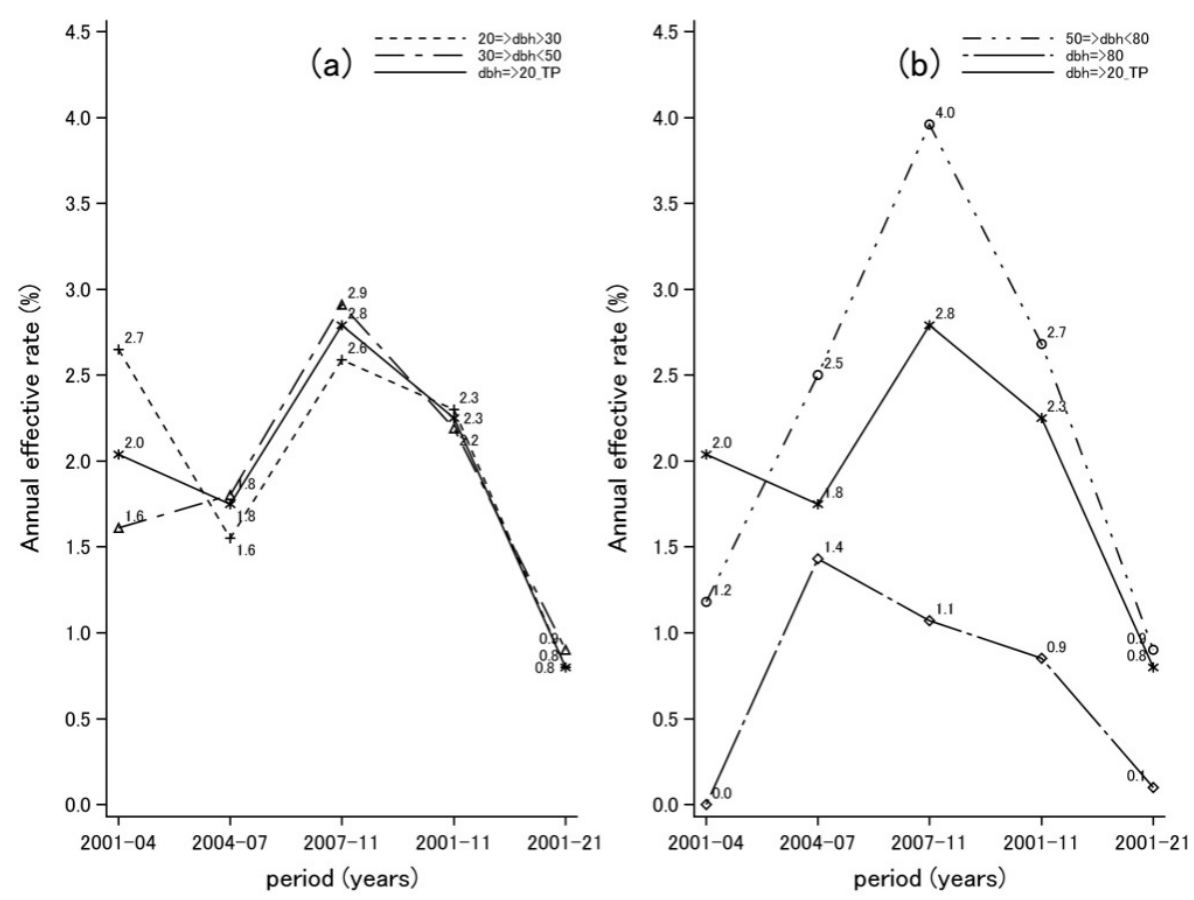

Figure 2. Mortality rates (expressed in effective annual rates) observed between 2001 and 2011 and forecast for between 2001 and 2021; $20 \geq \mathrm{dbh}>30$ : biomass with DBH greater than or equal to $20 \mathrm{~cm}$ and less than $30 \mathrm{~cm} ; 30$ $\geq \mathrm{dbh}>50$ : biomass with DAP greater than or equal to $30 \mathrm{~cm}$ and less than $50 \mathrm{~cm} ; 50 \geq \mathrm{dbh}>80$ : biomass with DAP greater than or equal to $50 \mathrm{~cm}$ and less than $80 \mathrm{~cm}$; dbh $>80$ : biomass with DAP greater than or equal to 80 $\mathrm{cm} ; \mathrm{dbh}>20$ : total tree density with $\mathrm{DBH}$ greater than or equal to $20 \mathrm{~cm}$

In the observed period, between 2001 and 2011 (Figure 2b), the highest annual mortality rate (4\%) occurred in the classes of $50 \leq \mathrm{DAP}<80 \mathrm{~cm}$. In the $\mathrm{DBH} \geq 80 \mathrm{~cm}$ classes, there was no mortality in the period between 2001 and 2004. The mortality rates of the $\mathrm{DBH} \geq 80 \mathrm{~cm}$ classes were lower in all studied periods. The forecast for the period between 2001 and 2021 demonstrates that all size classes showed annual mortality rates lower than $1 \%$ per year. The forecast for the large trees presents the lowest rate of $0.1 \%$ per year.

The observed and projected annual recruitment rate of trees $\mathrm{DBH} \geq 30 \mathrm{~cm}$ were similar (Figure 3 ), except for the $20 \leq$ DAP $<30 \mathrm{~cm}$ size class, where the projected rate was lower than that observed, because recruitment in this class is more difficult to predict in short periods (Figure 3). 


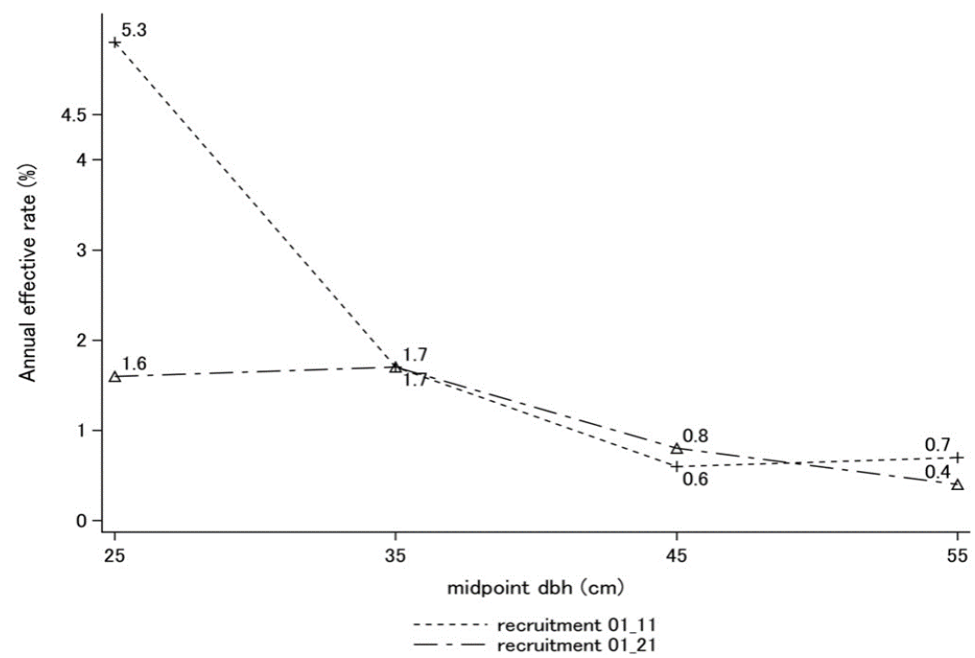

Figure 3. Annual effective recruitment rates according to DBH classes, observed from 2001 to 2011 and predicted with the Markov Chain for the period 2001 to 2021

\subsection{Economic Model}

The annual rates obtained by the Markov Matrices in the analysis for forest dynamics are presented together with the macroeconomic indexes used in the structuration of the economic model (Figure 4). The rate behavior was analyzed in two situations: i) in the period observed from 2001 to 2011; and ii) in the 2001 to 2021 forecast.

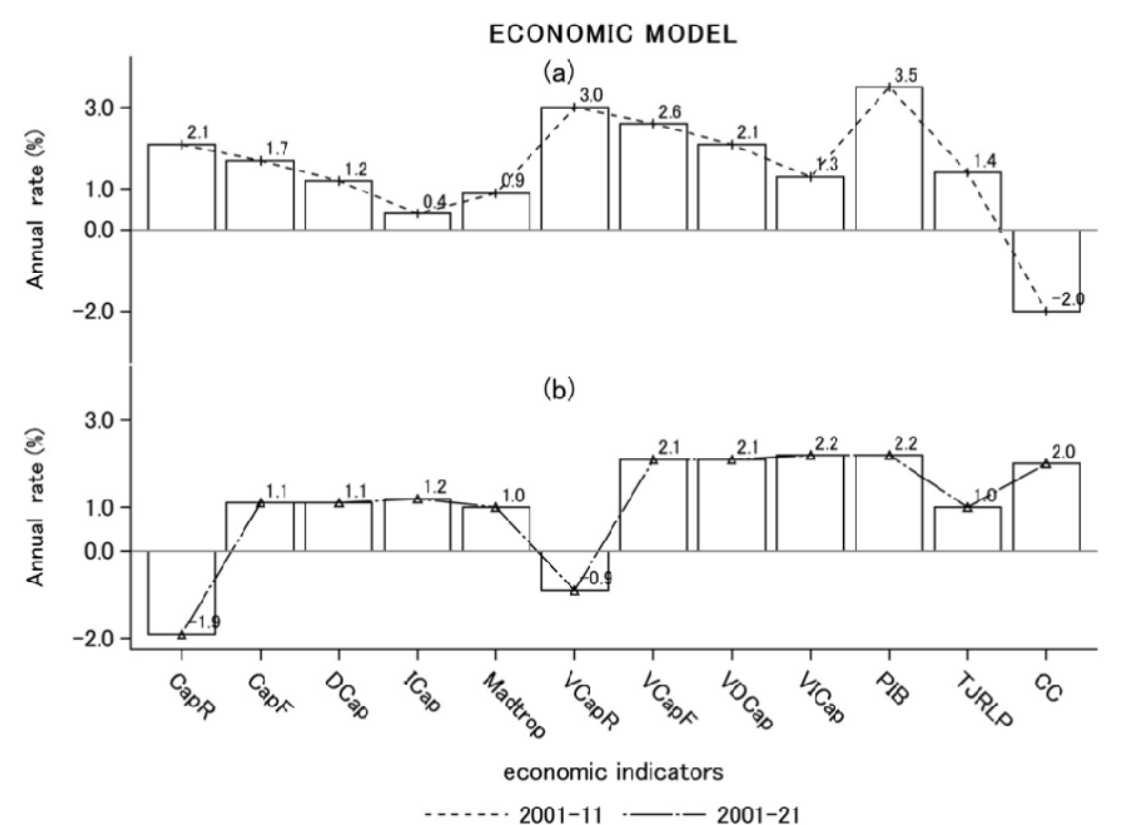

Figure 4. Economic model analysis of forest dynamics behavior in an area submitted to sustainable forest management in the Amazon. Annual rates observed between 2001 and 2011 (a), and the prognosis from 2001 to 2021. CapR: capital repositioning (DAP $\geq 20<30 \mathrm{~cm}$ ); CapF capital formation (DAP $\geq 30<50 \mathrm{~cm}$ ); DCap: available capital (DAP $\geq 50<80 \mathrm{~cm}$ ); ICap: immobilized capital (DAP $\geq 80 \mathrm{~cm}$ ); Madtrop: valuation of tropical wood in logs; VCapR: valuation of capital replenishment (DAP $\geq 20<30 \mathrm{~cm}$ ); VCapF: valuation of capital formation (DAP $\geq 30<50 \mathrm{~cm}$ ); VDCap: valuation of available capital (DAP $\geq 50<80 \mathrm{~cm}$ ); VICap: valuation of

fixed capital (DAP $\geq 80 \mathrm{~cm}$ ); GDP: gross domestic product-Brazil; TJRLP: long-term real interest rate; $\mathrm{CC}$ : exchange rate correction; annual rates (\%): annual rates (\%)

The annual average GDP rate observed between 2001 and 2018 and the one forecasted for 2021 resulted in 2\% per annum. The average annual rate of GDP for this period was lower than the observed rate of $3.5 \%$ per annum between 2001 and 2011. 
The long-term real interest rate was calculated by the ratio between the BNDES' $8.1 \%$ average annual long-term interest rate between 2001 and 2011 and the Brazilian average annual rate of inflation of $6.61 \%$ observed in the period from 2001 to 2011. The result was converted into US dollars by the annual exchange rate correction during that period of $-2 \%$, resulting in an average annual value of the real (net) long-term interest rate of $1.4 \%$ for the period (Figure 4a).

The annual average long-term interest rate (TRJLP) of 1\% per annum for the period between 2001 and 2021 was calculated from the ratio between the BNDES' average long-term annual rate of $7.25 \%$ predicted for the period from 2001 to 2021, and inflation in Brazil of $6.19 \%$ per year expected from 2001 to 2021. The result was converted into dollars using the average annual exchange rate correction of $2 \%$ predicted for the period from 2001 to 2021 (Central Bank of Brazil, 2017, 2018; BNDES, 2018).

From 2001 to 2011 the real (net) long-term interest rate (TJRLP) behaved similarly to the annual rates of economic categories without market valorization, except for Fixed Capital with an annual rate of $0.4 \%$ (Figure 4a). In the 2001 to 2021 forecast, the same occurs with the exception of the negative annual rate of $1.9 \%$ Capital Recovery (Figure 4b).

The forecast valuation of tropical timber (Madtrop) for the interval between 2001 and 2021 was 1 per cent per annum, calculated from the series of average international prices and forecasts for 2001 between imports and exports of tropical roundwood (ITTO, 2017). The calculation was made considering the price of USD $399 \mathrm{per} \mathrm{m}^{3}$ in 2014 and the price of USD 138 per $^{3}$ in 2001 and the forecasted rate for 2021 . The rate obtained for the range from 2001 to 2021 was $8.9 \%$ per year, and the commercial species participation factor of $0.11(11 \%)$ was applied to available capital, resulting in an equivalent annual rate of $1 \%$ per year (Figure 4 ).

The exchange rate correction calculated for the period from 2001 to 2011 had a negative annual rate of $2 \%$ and the prognosis from 2001 to 2021 was set at the annual rate of $2 \%$ (Figure 4).

The annual valuation rate showed that economic categories behave similarly to the annual rate of GDP and the annual exchange rate correction in the forecast between 2001 and 2021 (Figure 4b). Between 2001 and 2011 the valuation of the capital showed values close to the GDP, except the valuation of Capital Assets, which shows a value close to TJRLP (Figure 4a).

The valuation of tropical wood predicted between 2001 and 2021 was similar to that observed between 2001 and 2011.

\section{Discussions}

\subsection{Forest Dynamics and Forecast}

The application of the 'two steps forward' Markov Chain allowed the forest dynamics of the studied area to be analyzed in the interval from 2001 to 2011 and the parameters forecast to be made for 2021. This method also produced consistent results in previous studies carried out in the Brazilian Amazon (Higuchi, 1987; Teixeira et al., 2007; Vasconcelos et al., 2009; Acuña, 2015).

The Chi Square test did not show a significant difference between the forecast for 2021 and the tree density observed in 2016 when the DBH $\geq 20<30 \mathrm{~cm}$ diameter class was removed. The highest recruitment and mortality rates occurred in this size class.

The obtained annual rates of biomass increase for trees DBH $\geq 20 \mathrm{~cm}$, observed between 2001 and 2011, were similar to those found by D'Oliveira et al., (2017) in a similar forest in the same region. They were also similar to the results in other studies in dense and open ombrophilous terra-firme forests in Amazon (De Carvalho, 2004; Teixeira et al., 2007; Vasconcelos et al., 2009; Souza et al., 2012, 2017).

The forecasted rates for biomass increase from 2001 to 2021 were lower than those observed between 2001 and 2011, but similar to the literature (De Carvalho, 2004; Teixeira et al., 2007; Vasconcelos et al., 2009; Souza et al., 2012; D'Oliveira et al., 2017; Souza et al., 2017). The increase in annual biomass rates represents forest recovery after forest disturbance and can be used as an indicator to evaluate the behavior of forest dynamics and to estimate cutting cycles and silvicultural treatments.

The annual mortality rates from 2001 to 2011 found in our study (DBH $\geq 20 \mathrm{~cm}$ ) were similar to those in other Amazon sites in managed and non-managed areas in different forest types in different periods and monitoring times (Azevedo et al., 2008; Vasconcelos et al., 2009; Salomão et al., 2007; Santos et al., 2018).

The lowest annual mortality rate was observed between 2001 and 2011, ten years after logging, corresponding to the group of large trees (DAP $\geq 80 \mathrm{~cm}$ ) with $0.9 \%$. Vasconcelos et al. (2009) analyzed a dense ombrophilous forest associated with open ombrophilous forest and found an annual mortality rate of $3.2 \%$ per year in this 
group between 1997 and 2001, four years after logging. The highest annual mortality rate of 4\% was found between 2007 and 2011, seven to ten years after logging, in the group of trees with $30 \leq \mathrm{DBH}<50 \mathrm{~cm}$, a similar result to that found by D'Oliveira and Braz (1998), and Vasconcelos et al. (2009) for this stratum, five and four years, respectively, after logging.

Recruitment of new trees (DBH $\geq 20 \mathrm{~cm}$ ) between 2001 and 2011 was greater than the 2001 to 2021 annual forecasted rate, but similar to rates found by D'Oliveira et al. (2017), 20 years after logging. Recruitment in the present study was higher than the results of De Carvalho (2004), Teixeira et al. (2007), and Azevedo et al. (2008) in experimental forests, or of Vasconcelos et al. (2009); Souza et al. (2012, 2017); Salomão et al. (2017); Santos et al. (2018). The results obtained through the use of the Markov Chains were robust enough to evaluate the parameters of the forest dynamic from 2001 and 2011 and to predict to 2021.

\subsection{Economic Model}

The economic model was able to compare the annual rates of forest dynamics of an area under sustainable forest management in the Amazon with the macroeconomic indicators used.

The average annual rate of GDP between 2001 and 2011 remained at levels of $3.5 \%$ due to a strong process of credit increase in Brazil, increasing its participation from around 27\% of the GDP in 2003 to more than $50 \%$ in 2011. The credit increase was produced by the adoption of payroll loans, changes in credit legislation for automobile acquisition and changes in the legislation for mortgages (IPEA, 2017).

From 1994 to 2008, the GDP of the Brazilian Forestry Sector, with an average annual rate of 1.3\%, decreased its share in the Brazilian GDP. The fiscal incentives implemented since 1965 to stimulate the forestry sector were restricted in 1988, although the sector continued to contribute to Brazil's GDP at lower levels through financing from the BNDES and development banks. From 1999, there was growth of the nominal GDP of the forest sector due to the increase of the prices of forest products, even with the reduction of the fiscal incentives for the sector (IPEA, 2017; Soares et al., 2014).

The forestry sector finances its productive activities through the National Rural Credit System created by the Brazil's Central Bank, obtaining resources, for the most part, from the BNDES. The TJRLP calculated by our study resulted in a 1.4\% per annum between 2001 and 2011 and 1\% per year projected between 2001 and 2021. In 2018, the BNDES replaced the TJLP with the long-term rate (TLP). In the period between 2014 and 2017, the TJLP remained at the level of 7\% per year. The TLP from 2018 and forecasts until 2021 maintain the same level of 7\% per year as the TJLP between 2001 and 2017. The IPCA decelerated in annual rates from $2017(2.9 \%)$ and $2018(3.8 \%)$. The forecast for 2019 shows a rate of 4\%, and for 2020 and 2021 a rate of 3.8\% (Central Bank of Brazil, 2019).

The tropical timber valuation rate maintained its annual growth even with the $28 \%$ drop in European imports at the end of September 2017 (ITTO, 2018). This trend was also observed in 2018, when tropical timber exports to EU countries fell by $31 \%$ compared to the same period in 2016. In 2016, the average price of world exports of tropical roundwood represented an annual growth rate equivalent to $8.7 \%$ (ITTO, 2017). In the period between 2001 and 2008, the valuation rate of tropical roundwood in the Brazilian market was 9.7\% per year (Santana et al., 2010). The valuation of tropical wood in our study only considered species with a market value, which remained on average $11.0 \%$ of the capital analyzed during the measurements. To the remaining $89 \%$ AGB no value was attributed due to absence of market parameters.

\section{Conclusions}

The proposed economic model allowed the comparison of forest dynamics growth parameters by transforming tree size classes into economic categories, with observed and forecasted macroeconomic parameters.

The forest dynamics parameters of mortality, recruitment and growth allowed us to evaluate natural impacts in a relatively short analysis period (10 years), and to forecast them in macroeconomic terms over time.

The forest growth parameters predicted by the Markov Chain for size classes evaluated with DBH equal to or greater than $20 \mathrm{~cm}$ were equivalent to the GDP projected for 2001 and 2021. The results allow us to conclude that under the conditions of this work the forest management applied to the area was economically viable, presenting yields similar to those observed and predicted for the Brazilian economy.

\section{Acknowledgements}

We would like to thank the Brazilian Agricultural Research Corporation in Acre, the National Research Council, the Commission for the Improvement of Higher Education, the Federal University of Acre and the Brazilian 
Network of Federal Universities of the Legal Amazon for their support and for making resources available for this proposal.

\section{References}

Acuña, M. H. A. (2015). Análise ecointegradora do manejoflorestal sustentável de estoques madeireiros na Amazônia sul ocidental-Brasil (Dissertação de Mestrado, Universidade Federal do Acre, Brazil).

Azevedo. C. P., Sanquetta, C. R., \& Silva, J. N. M. (2008). Efeito de diferentesníveis de exploração e de Tratamentos silviculturais sobre a dinâmica da floresta remanescente. Floresta, 38(2). https://doi.org/10.5380/ rf.v38i2.11622

BACEN (Banco Central do Brasil). (2018). Tabela de metas e resultados: 2017; 2018. Retrieved from http://www.bcb.gov.br/Pec/metas/TabelaMetaseResultados.pdf

Baker, T. R., Phillip, O. L., Malhi, Y., Almeida, S., Arroyo, L., DiFiore, A., ... Vasquez, R. M. (2004). Increasing biomass in Amazon forest plots. The Royal Society, 359, 353-365. https://doi.org/10.1098/rstb.2003.1422

Blanc, L., Echard, M., Herault, B., Bonal, D., Marcon, E., Chave, J., \& Baraloto, C. (2009). Dynamics of above ground carbon stocks in a selectively logged tropical forest. Ecological Applications, 19(6), 1397-1404. https://doi.org/10.1890/08-1572.1

BNDES (Banco Nacional de Desenvolvimento Brasil). (2018). Taxa de juros de longo prazo: Evolução. Retrieved from https://www.bndes.gov.br/wps/portal/site/home

Boisvenue, C., \& Running, S. W. (2006). Impacts of climate change on natural forest productivity-evidences in the middle of the 20th century. Global Change Biology, 12, 862-882. https://doi.org/10.1111/j.1365-2486. 2006.01134.x

Carpintero-Redondo, O. (1999). Entre la economia y lanaturaleza: La controvérisa sobre la valoración monetária del medio ambiente y la sustentabilidade del sistema económico (p. 383). Madrid: Livros de la Catarata.

CDB (Convenção da Diversidade Biológica). (2010). Key Elements of the Strategic Plan 2011-2020, Including Aichi Biodiversity Targets. Secretariado da Convenção Sobre Diversidade Biológica. Retrieved from http://www.cbd.int/sp/elements

Costa, C. A. F. Da, \& Montysuma, M. F. F. (2016). Racionalidade do dinheiro: Contrapontos à racionalidade ambiental (p. 184). Jundiaí: Paco Editorial.

D'Oliveira M, V. N., Oliveira, L. C., Acuña, M. H. A., \& Braz, E. M. (2017). Twenty years monitoring growth dynamics of a logged tropical forest in Western Amazon. Brazilian Journal of Forestry Research, 37(92), 493-502. https://doi.org/10.4336/2017.pfb.37.92.1398

D’Oliveira, M. V. N., \& Braz, E. M. (1998). Manejo florestal em regime de rendimento sustentado aplicado à floresta do campo experimental da EMBRAPA Acre. Boletim de Pesquisa, 21, 46.

D’Oliveira, M. V. N., Guarino, E. de S., Oliveira, L. C., Ribas, L. A., \& Acuña, M. H. A. (2013). Can forest management be sustainable in a bamboo dominated forest? A 12-years study of forest dynamics in western Amazon. Forest Ecologyand Management, 310, 672-679. https://doi.org/10.1016/j.foreco.2013.09.008

Daly, H. E. (2004). Ecological Economics: Principles and applications (p. 484). Library of Congress, Washington, USA.

de Carvalho, J. O. P., Silva, J. N. M. da, \& Lopes, J. C. A. (2004). Growth rate of a terra firma rainforest in Brazilian Amazonia over an eight-year period in response to logging. Acta Amazonia, 34, 209-217. https://doi.org/10.1590/S0044-59672004000200009

de Souza, M. A. S., Azevedo, C. P. de, Souza, S. R. de, França, M., \& Neto, E. L. V. (2017). Dinâmica e produção de uma floresta sob regime de manejo sustentável na Amazônia central. Floresta, Curitiba, 47(1), 55-63. https://doi.org/10.5380/rf.v47i1.43312

FAO-ONU. (2015). Organização das Nações Unidas para a Alimentação e a Agricultura. Relatório: El estado de los recursos de suelos em el mundo. Escritório Regional da FAO para a América Latina e o Caribe. Retrieved from http://www.fao.org/americas/noticias/ver/pt/c/360627

FMI (Fundo Monetário Internacional). (2017). Previsão de crescimento econômico do Brasil. Retrieved from http://epocanegocios.globo.com/Economia/noticia/2017/04/epoca-negocios-fmi-brasil-deve-crescer-02-em2017-e-projecao-para-pib-de-2018-sobe-a-17.html 
FMI (Fundo Monetário Internacional). (2018). Previsão de crescimento econômico do Brasil. Retrieved from https://br.reuters.com/article/businessNews/idBRKBN_1_CF1NW-OBRBS

FUNTAC (Fundação de Tecnologia do Acre). (1989). Inventário Florestal e diagnóstico da regeneração natural da Floresta Estadual do Antimary do Programa de Desenvolvimento Rural Integrado do Estado do Acre, $P D R I / A C$ (p. 151). Rio Branco: INPA.

Georgescu-Roegen, N. (1971). The entropy law and the economic process (p. 450). Harvard University Press, Cambrigde. https://doi.org/10.4159/harvard.9780674281653

Higuchi, N. (1987). Short-term growth of an undisturbed tropical moist Forest in the Brazilian Amazon (p. 129). Michigan: Michigan StateUniversity.

Higuchi, N., \& Clement, C. R. (2006). A Floresta Amazônica e o futuro do Brasil. Manaus: Amazônia Artigos.

IPEAa (Instituto de Pesquisa Econômica Aplicada). (2017). Impactos Macroeconômicos da Expansão do Crédito no Brasil: O periodo 2001-2011. Texto Para Discussão.

IPEAb (Instituto de Pesquisa Econômica Aplicada). (2010). Retrieved from http//:www.ipeadata.gov.br

ITTO (International Tropical Timber Organization). (2012-2018). Market information service. Annual Report. Retrieved from http://www.itto.int/es/market information service/?err $=1 \&$ Retrun URL $=\% 2 \mathrm{Fmis}$ detail $\% 2 \mathrm{~F}$

Kolmogorov, A. N., \& Aleksandrov, A. D. (1956). Mathematics: Its Content. Methods and Meaning (p. 372 ).

Naredo, J. M. (1987). La economia en evolución: História y perspectivas de las categorías básicas del pensamento económico (p. 539). Madrid: Siglo Veintiuno Editores S.A.

Negrón-Juarez, R. I., Chambers, J. Q., Guimaraes, G., Zeng, H., Raupp, C. F. M., Marra, D. M., Higuchi, N. (2010). Amazon forest tree mortality from a single cross-basin squall line event. Geophysical Research Letters, 37, 1-5. https://doi.org/10.1029/2010GL043733

Nepstad, D. (2004). Amazon drought and its implications for forest flammability and tree growth: A basin-wide analysis. Global Change Biology, 10, 704-717. https://doi.org/10.1111/j.1529-8817.2003.00772.x

Nogueira, E. M., Fearnside, P. M., Nelson, B. W., Barbosa, R. I., \& Keiser, E. W. H. (2008). Estimates of forest biomass in the Brazilian Amazon: New allometric equations and adjustments to biomass from wood-volume inventories. Forest Ecology and Management, 256, 1853-1867. https://doi.org/10.1016/j.foreco.2008. 07.022

OECD (Organisation for Economic Co-operation and Development). (2009). La bioéconomie à l'horizon 2030. Quel programme d'action? France.

Pan, Y., Birdsey, R. A., Fang, J., Houghton, R., Kauppi, P. E., Kurz, W. A., ... Hayes, D. (2011). A large and persisten carbon sink in the World's Forests. Science, 33, 988-993. https://doi.org/10.1126/ science.1201609

Salomão, R. P., Rosa, N. A., \& Morais, K. A. M. (2007). Dynamics of natural tree regeneration after strip-mining in the Amazon. Bol. Mus. Para. Emílio Goeldi. Ciências Naturais, 2(2), 85-139.

Sanquetta, C. R., Brena, D. A., Angelo, H., \& Mendes, J. B. (1996). Matriz de transição para simulação da dinâmica de florestas naturais sob diferentes intensidades de corte. Ciência Florestal, 6(1), 65-78. https://doi.org/10.5902/19805098326

Santana, A. C. de, Santos, M. A. S. dos, \& Oliveira, C. M. de. (2010). Comportamento histórico da produção e comércio de madeira do estado do Pará nos mercados local e internacional. Amazônia: Ciência \& Desenvolvimento, 6(11).

Santos, F. G., Camargo, P. B. de, \& Oliveira, R. C. de. (2018). Stocks and dynamics of tree biomass in tropical rain forest in the Tapajos National Forest, Eastern Amazon. Ciência Florestal, 28(3), 1049-1059. https://doi.org/10.5902/1980509833388

Schneider, P. R. (2004). Manejo Florestal: Planejamento da produção florestal (p. 493). Centro de Ciências Rurais, Departamento de Ciências Florestais, Universidade Federal de Santamaria, Santa Maria.

Sheil, D., Jennings, S., \& Savill, P. (2000). Long-term permanent plot observations of vegetation dynamics in Budongo, a Ugandan rain forest. Journal of Tropical Ecology, 16, 765-800. https://doi.org/10.1017/S0266 467400001723

Soares, N. A., Silva, M. L. da, \& Cordeiro, S. A. (2014). Produto interno bruto do setor florestal brasileiro, 1994 a 2008. Arvore, 38(4), 725-732. https://doi.org/10.1590/S0100-67622014000400015 
Souza, C. R. de, Azevedo, C. P. de, Rossi, L. M. B., Silva, K. E. da, Santos, J. dos, \& Higuchi, N. (2012) Dinâmica e estoque de carbono em floresta primária na região de Manaus/AM. ACTA Amazônica, 42(4), 501-506. https://doi.org/10.1590/S0044-59672012000400007

Souza, M. A. S. de, Azevedo, C. P. De, Souza, C. R. De, França, M., \& Vasconcelos Neto, E. L. (2017). Dinâmica e produção de uma floresta sob regime de manejo sustentável na Amazônia Central. Floresta. Curitiba, 47(1), 55-63. https://doi.org/10.5380/rf.v47i1.43312

Teixeira, L. M., Chambers, J. C., Silva, A. R. E., Lima, A. J. N., Carneiro, V. M. C., Santos, J. dos, \& Higuchi, N. (2007). Projeção da dinâmica da Floresta Natural de Terra Firme, região de Manaus-AM com uso da Cadeia de Transição Probabilística de Markov. ACTA Amazônica, 37(3), 377-384. https://doi.org/10.1590/ S0044-59672007000300009

Toledo, M., Ferry, B., Bontemps, J. D., Blanc, L., \& Baraloto, C. (2011). Climate is a stronger driver of tree and forest growth rates than soil and disturbance. Journal of Ecology, 99, 254-264. https://doi.org/10.1111/ j.1365-2745.2010.01741.x

Vasconcelos, S. S., Hiuchi, N., \& D’Oliveira, M. V. N. de. (2009). Projeção da distribuição diamétrica de uma floresta explorada seletivamente na Amazônia Ocidental. ACTA Amazônica, 39, 71-80. https://doi.org/ 10.1590/S0044-59672009000100007

Weigrand, R. Jr., Silva, D. C. da, \& Silva, D. de O. e. (2011). Metas do AICHI: Situação atual no Brasil. Diálogos sobra a biodiversidade: Construindo a estratégia do Brasil para 2020. Brasília. DF: UICN. WWF-Brasil e IPE.

West, T. A. P., Vidal, E., \& Putz, F. E. (2014). Forest biomass recovery after conventional and reduced-impact logging in Amazonian Brazil. Forest Ecology and Management, 314, 59-63. https://doi.org/10.1016/ j.foreco.2013.11.022

\section{Copyrights}

Copyright for this article is retained by the author(s), with first publication rights granted to the journal.

This is an open-access article distributed under the terms and conditions of the Creative Commons Attribution license (http://creativecommons.org/licenses/by/4.0/). 